Published in final edited form as:

J Med Chem. 2006 March 9; 49(5): 1773-1780.

\title{
Design and Synthesis of Novel Hydrazide-Linked Bifunctional Peptides as $\delta / \mu$ Opioid Receptor Agonists and CCK-1/CCK-2 Receptor Antagonists
}

\author{
Yeon Sun Lee ${ }^{\dagger}$, Richard S. Agnes ${ }^{\dagger}$, Hamid Badghisi ${ }^{\ddagger}$, Peg Davis $\ddagger$, Shou-wu Ma ${ }^{\ddagger}$, Josephine \\ Lai ${ }^{\ddagger}$, Frank Porreca ${ }^{\ddagger}$, and Victor J. Hruby ${ }^{\star}, \dagger$ \\ Departments of Chemistry and Pharmacology, University of Arizona, Tucson, Arizona 85721
}

\begin{abstract}
A series of hydrazide-linked bifunctional peptides designed to act as agonists for $\delta / \mu$ opioid receptors and antagonists for CCK-1/CCK-2 receptors was prepared and tested for binding to both opioid and CCK receptors and in functional assays. SAR studies in the CCK region examined the structural requirements for the side chain groups at positions $1^{\prime}, 2^{\prime}$, and $4^{\prime}$ and for the N-terminal protecting group, which are related to interactions not only with CCK, but also with opioid receptors. Most peptide ligands that showed high binding affinities $(0.1-10 \mathrm{nM})$ for both $\delta$ and $\mu$ opioid receptors generally showed lower binding affinities (micromolar range) at CCK-1 and CCK-2 receptors, but were potent CCK receptor antagonists in the GPI/LMMP assay (up to $\mathrm{Ke}=6.5 \mathrm{nM}$ ). The results indicate that it is reasonable to design chimeric bifunctional peptide ligands for different G-protein coupled receptors in a single molecule.
\end{abstract}

\section{Introduction}

Nerve injury associated pain, neuropathic pain, is very difficult to treat, and the underlying mechanisms of this condition are not fully understood. Preclinical studies have shown that a significant consequence of injuries to peripheral nerves is an increase in the expression of the endogenous peptide cholecystokinin $\left(\mathrm{CCK}^{\mathrm{a}}\right)$ in rodents. CCK is known to act via two types of receptors, termed CCK-1 and CCK-2. CCK has been shown to reduce the antinociceptive effects of opioids at a number of CNS sites, particularly in the spinal cord and in the brainstem, as well as eliciting a direct pronociceptive action. ${ }^{1-5}$ Among the three $(\delta, \mu, \kappa)$ opioid receptor subtypes, the activation of $\mu$ and $\delta$ opioid receptors produces antinociception; most clinically used opioid drugs, including morphine, are $\mu$ opioid agonists. Acute blockade of spinal and supraspinal CCK receptors enhances the antinociceptive potency of morphine and may also prevent or reverse the development of tolerance to opioids. ${ }^{6-9}$

\footnotetext{
* To whom correspondence should be addressed. Tel: (520)-621-6332. Fax: (520)-621-8407. E-mail: hruby @u.arizona.edu..

$\dagger^{\dagger}$ Department of Chemistry.

\$Department of Pharmacology.

Supporting Information Available: ${ }^{1} \mathrm{H}$ NMR data. This material is available free of charge via the Internet at http://pubs.acs.org.

aAbbreviations: Ac, acetyl; AcOH, acetic acid; Adoc, adamantyloxy-carbonyl; Boc, tert-butyloxycarbonyl; BOP, (benzotriazole-1yloxy) tris-(dimethylamino) phosphonium hexafluorophosphate; $\mathrm{BuOH}$, butanol; Bzl, benzyl; CCK, cholecystokinin; CHO, Chinese hamster ovary; CNS, central nervous system; Cpac, $o$-chlorophenylaminocarbonyl; DCC, $N, N$-dicyclo-hexylcarbodiimide; DCU, $N, N$ dicyclohexylurea; DMF, $N, N$-dimethylform-amide; DMSO, dimethyl sulfoxide; hDOR, human $\delta$ opioid receptor; DPDPE, c[D$\mathrm{Pen}^{2}, D$-Pen $\left.{ }^{5}\right]$ enkephalin; DAMGO, $\left[D-\mathrm{Ala}^{2}, \mathrm{NMePhe}^{4}, \mathrm{Gly}^{5}\right.$-ol] enkephalin; EtOAc, ethyl acetate; GPCR, G-protein coupled receptor; GPI, guinea pig isolated ileum; HEK, human embryonic kidney; HOBt, 1-hydroxybenzotriazole; LMMP, longitudinal muscle with myenteric plexus; rMOR, rat $\mu$ opioid receptor; MVD, mouse vas deferens; NMM, $N$-methylmorpholine; PG, protecting group; Pya, pyrenylalanine; SAR, structure-activity relationships; TFA, trifluoroacetic acid; Tac, toluenylaminocarbonyl.
} 
From this background, we have hypothesized that the development of novel ligands that possess properties of antagonists at CCK receptors and of agonists at the opioid receptors, within the same molecule, may present a significant therapeutic advantage in the treatment of pain states and enhanced analgesic effect in chronic pain states such as neuropathies and analgesia without the development of tolerance. ${ }^{10,11}$ This novel idea came out of our earlier discovery that suggested that CCK- 2 and $\delta$ opioid receptors have overlapping topographical structural pharmacophores for their agonist ligands 6,7 and led us to develop SNF9007, which interacts with both the CCK-2 and $\delta$ opioid receptors. ${ }^{14}$

We have designed novel bifunctional peptide ligands where both opioid and CCK pharmacophores are fused (Figure 1). We combined opioid and CCK pharmacophores through a hydrazide linker so that the designed bifunctional peptide ligands maintain topologically related structures to both pharmacophores. For the opioid agonist pharmacophore, the halfstructure of biphalin (Tyr-D-Ala-Gly-Phe-NH-), which has remarkable efficacy at both $\delta$ and $\mu$ opioid receptors, ${ }^{15}$ was chosen. And for the CCK antagonist pharmacophore, $\mathrm{CCK}_{30-33}$ (Trp-Met-Asp-Phe- $\mathrm{NH}_{2}$ ) was selected and modified in different positions to optimize CCK activities while opioid activities are retained (Figure 2).

Our aim was to develop novel CCK antagonist and opioid agonist activities in one structure using two known pharma-cophores as the starting point. A desired requirement was balanced CCK-1 and CCK-2 antagonist activities, together with agonist activities at both $\delta$ and $\mu$ opioid receptors. The designed and synthesized peptide ligands were evaluated for (1) their opioid binding affinities at the human $\delta$ opioid receptor (hDOR) and the rat $\mu$ opioid receptor (rMOR) in competition assays against standard radioligands using cells that express with these receptors; (2) their opioid efficacies using the $\left[{ }^{35} \mathrm{~S}\right] \mathrm{GTP}-\gamma$-S binding assay; (3) their $\delta / \mu$ opioid agonist activities in stimulated isolated mouse vas deferens (MVD) and guinea pig isolated ileum (GPI) bioassays, respectively; (4) their CCK-1 and CCK-2 receptor binding affinities in competition assays against standard radioligands using transfected cells that express the hCCK-1 or hCCK-2 receptors; and (5) their antagonism and agonism of CCK receptors in the unstimulated GPI/longitudinal muscle with myenteric plexus (LMMP). The success of this approach is reflected in the biological activity of the series of hydrazide-linked bifunctional peptide ligands. This new series was optimized to give a number of desirable bifunctional activities for opioid and CCK receptors.

\section{Results and Discussion}

\section{Synthesis}

Bifunctional peptide ligands were prepared stepwise by the solution-phase method using Boc/ Bzl-chemistry. The synthetic strategy for preparation of ligands involved four key steps: (1) stepwise chain elongation starting from Phe-OEt, (2) hydrazine substitution, (3) stepwise chain elongation on the tetrapeptide hydrazide, and (4) hydrogenation (Figure 3). During the chain elongation, peptide intermediates were isolated by precipitation from appropriate organic solvents or $5 \% \mathrm{NaHCO}_{3}$ solution with high purity and finally deprotected by hydrogenation to give target peptide ligands with more than $90 \%$ crude purity. These were purified by preparative RP-HPLC to give pure (>98\%) hydrazide-linked peptides (see Table 1 for analytical data).

\section{Structure-Activity Relationships}

As shown in Figure 1, rational design of the peptides that demonstrate activity as an opioid agonist and a CCK antagonist was accomplished by combining opioid and CCK pharmacophores through a hydrazide linker. The hydrazide linker should not interfere with binding interactions with both receptors. And key side chain groups of both pharmacophores 
could serve for molecular recognition at both opioid and CCK receptors. For the opioid receptors, the two key pharmacophore elements are the phenylalanine and tyrosine residues and, for the CCK receptors, the indole group of tryptophan, the phenyl group for phenylalanine, and possibly a carboxyl group from aspartic acid. Considering these points, the $\mathrm{C}$-terminus of a opioid agonist structure (Tyr- $D$-Ala-Gly-Phe-), which is the half-structure of biphalin, ${ }^{15}$ and the CCK agonist structure (Trp-Met-Asp-Phe-), which is $\mathrm{CCK}_{30-33}$, were linked through a hydrazide. To ensure an antagonist function for CCK, the Trp residue was replaced by $D$-Trp. 16 Met was substituted by Nle in the way not to change their character but to avoid unnecessary side reactions. The $2^{\prime}$ and $4^{\prime}$ positions of the CCK portion were $N$-methylated in some cases to give increased backbone constraint, and the $\mathrm{N}$-terminal protecting groups were modified to optimize the biological activity and physicochemical properties. The N-terminus of the Tyr residue on the opioid part was not blocked because it was known that the free amine group plays an important role in opioid activity.

Opioid binding affinities of these ligands for the human $\delta$ opioid receptor (hDOR) or the rat $\mu$ opioid receptor (rMOR) were determined by radioligand competition analysis using $\left[{ }^{3} \mathrm{H}\right] \mathrm{c}$ $\left[D\right.$-Pen ${ }^{2}, D$-Pen $\left.{ }^{5}\right]$ enkephalin (DPDPE) to label the $\delta$ opioid receptor and $\left[{ }^{3} \mathrm{H}\right][D-$

$\mathrm{Ala}^{2}, \mathrm{NMePhe}^{4}, \mathrm{Gly}^{5}$-ol] enkephalin (DAM-GO) to label the $\mu$ opioid receptor in cell membrane preparations from transfected cells that stably express the respective receptor type. CCK binding affinities were evaluated by competition analysis using $\left[{ }^{125} \mathrm{I}\right] \mathrm{CCK}-8\left(\mathrm{SO}_{3}\right)$ to label membranes from HEK293 cells that express either the human CCK-1 or human CCK-2 receptors. In Table 2, most of the synthesized peptide ligands showed high binding affinities at both $\delta$ and $\mu$ opioid receptors in the nanomolar range with slight $\delta$ or $\mu$ selectivity and lower but well-balanced binding affinities at CCK-1 and CCK-2 receptors in the micromolar range. No selectivity (0.5-2, except for 6 ) for CCK-1 or CCK-2 binding affinities was seen, which can be significant when considering the possible role of balanced CCK-1 and CCK-2 antagonists in the treatment of pain states. ${ }^{17}$ There have been observations 18,19 that show that although both CCK-1 and CCK-2 receptors may exist in the brain, the CCK-2 receptor predominates in the dorsal horn of the spinal cord of rodents, whereas the CCK-1 receptor predominates in that of the primate. This observation is important in that it suggests that blockade of both CCK-1 and CCK-2 receptors may be critical for efficacy in humans.

We used $\left[{ }^{35} \mathrm{~S}\right] \mathrm{GTP}-\gamma-\mathrm{S}$ binding to examine opioid agonist efficacy, for functional characterization of the ligands at the $\delta$ and $\mu$ opioid receptors. ${ }^{20}$ Classical functional assays also were performed to evaluate their opioid agonist activities in the GPI $(\delta)$ and MVD $(\delta)$. The assay result was generally comparable with the $\left[{ }^{35} \mathrm{~S}\right] \mathrm{GTP}-\gamma-\mathrm{S}$ binding assay. Most ligands exhibited better agonist activity for $\delta$ opioid receptor $\left(\mathrm{EC}_{50}=0.53-74 \mathrm{nM}, \mathrm{IC}_{50}=5.1-230\right.$ $\mathrm{nM})$ than $\mu$ opioid receptor $\left(\mathrm{EC}_{50}=0.64-210 \mathrm{nM}, \mathrm{IC}_{50}=28\right.$ to none $)$ in functional assays and GTP binding assays (Tables 3 and 4).

In vitro functional bioactivity was determined by measuring the inhibition against the CCK-8induced muscle contraction using unstimulated GPI/LMMP for CCK receptor antagonist activity (Table 4). The Ke values, calculated from the $\mathrm{IC}_{50}$ values of the reference agonist CCK-8, of ligands 1-9 (Table 4) were between 1 and $100 \mathrm{nM}$, except for ligand 7, which is only a partial CCK agonist with no antagonist activity. All other ligands tested had no CCK agonist activity.

The best result in all three assays occurred when $\mathrm{Phe}^{4^{\prime}}$ was replaced with NMePhe and when the $D$-Trp ${ }^{1^{\prime}}$ was replaced with $\operatorname{Trp}^{1^{\prime}}$ and the amino function of the residue was protected with an acetyl group to give $\mathbf{8}$. As can be seen in Tables $2-4$, ligand $\mathbf{8}$, which satisfies many of the criteria we set out in our design, showed agonist activity at $\delta$ and $\mu$ opioid receptors and antagonist activity at CCK receptors, though the CCK binding affinities were quite low. Interestingly, this ligand showed the highest agonist activity for the $\delta$ opioid receptor both in 
the $\left[{ }^{35} \mathrm{~S}\right] \mathrm{GTP}-\gamma$-S binding assay and in the functional assay (MVD) with $\mathrm{EC}_{50}=0.53 \mathrm{nM}$ and $\mathrm{IC}_{50}=5.1 \mathrm{nM}$, respectively. It also had somewhat better antagonist activity with a $\mathrm{Ke}=38$ $\mathrm{nM}$ at the GPI/LMMP than expected on the basis of the binding data. It is likely that the enhanced $\delta$ opioid receptor activity and selectivity over the $\mu$ receptor is because of the $\mathrm{NMe}$ modification on the $\mathrm{Phe}^{4^{\prime}}$ residue, which is closer to the opioid portion of the ligand. The structure-activity relationships for the $\delta$ and $\mu$ opioid receptors in the CCK pharmacophore will be discussed later in detail.

Ligand 1, in which the Nle and $D$-Trp residues were replaced at positions $2^{\prime}$ and $1^{\prime}$ in the CCK region instead of Met and Trp of $\mathrm{CCK}_{30-33}$ with a Boc protecting group, showed moderately high opioid binding affinities at both $\delta$ and $\mu$ receptors but low CCK-1 and CCK-2 binding affinities $\left(K_{\mathrm{i}}>10 \mu \mathrm{M}\right)$. It was interesting that very good CCK antagonist activity $(6.5 \mathrm{nM}$; see Table 4) was shown in the unstimulated GPI/LMMP assay, 21,22 which is a commonly used index for CCK-1, even though low binding affinities at CCK receptors were obtained. There were some differences in binding affinities for CCK receptors and for CCK antagonist activity at the unstimulated GPI/LMMP. While the ligands showed CCK antagonist activity at the unstimulated GPI/LMMP, several ligands did not bind to the CCK receptors well in the cloned receptors. These differences are considered to be from possible allosteric effects and need further investigation. As a starting point, ligand $\mathbf{1}$ was modified in different positions to increase CCK activity. For structure-activity relationships of the CCK pharmacophore of these hydrazide-linked bifunctional peptides, the following structural and positional modifications were made: (1) variation of the N-terminal protecting group, (2) inversion of chirality of the $\mathrm{N}$-terminal amino acid, (3) $\mathrm{N}$-methylation of the Nle in position $2^{\prime}$ and the Phe in position 1', and (4) introduction of known amino acid derivatives in position $3^{\prime} .^{23}$ Aspartic acid in the $2^{\prime}$ position of CCK pharmacophore was not changed, because it has been known that its modification leads to a marked decreases in CCK potency. $24-25$

It was shown that the $\mathrm{N}$-terminal protecting group of the CCK pharmacophore plays an important role in CCK binding affinities. ${ }^{26}$ The N-terminal of the CCK pharmacophore was substituted with different protecting groups such as Boc, Ac, and adamantyloxycarbonyl (Adoc) groups. Interestingly, these modifications affected not only binding affinities at CCK receptors (more than 18-fold) but also (up to 200-fold) binding affinities for opioid receptors (see 1-4 in Table 2). Substitution of hydrophobic and bulky group such as 1-Adoc or 2-Adoc resulted in increased binding affinities at both CCK-1 and CCK-2 receptors. In the case of the 1-Adoc group modification, much more increased $\delta$ opioid activity $\left(K_{\mathrm{i}}=0.23 \mathrm{nM}\right)$ and selectivity $(\mu / \delta=430)$ over $\mu$ opioid receptor was seen in binding assays. Although there was no clear explanation for the lowest $\mu$ opioid binding affinity of ligand $\mathbf{2}$ with the 1-Adoc substitution, compared with ligand $\mathbf{3}$ containing the 2-Adoc substitution, ligand $\mathbf{2}$ still showed the best functional activity in the GTP- $\gamma$-S binding assay (Table 3). Deletion of the N-terminal protecting group decreased both CCK-1 and CCK-2 binding affinities somewhat but increased both $\delta$ and $\mu$ opioid binding affinities, especially at the $\mu$ receptor. The binding result coincided with GTP- $\gamma$-S binding and even functional assays in the MVD and GPI (Table 4), which demonstrated that the $\mathrm{N}$-terminal protecting group in CCK pharmacophore plays an important role in determining opioid activities. Ligand $\mathbf{4}$, without an $\mathrm{N}$-terminal protecting group in the CCK region, showed high $\delta / \mu$ opioid activities in both binding and GTP- $\gamma-\mathrm{S}$ assays and a distinct increase in $\mu$ opioid activity in the GPI functional assay $\left(\mathrm{IC}_{50}=81 \mathrm{nM}\right)$. Even though the ligand showed reduced CCK binding affinities, it still retained moderate CCK antagonist activity $(\mathrm{Ke}=60 \mathrm{nM})$. Derivatization of peptides at the $\mathrm{N}$-or $\mathrm{C}$-terminus has frequently been carried out in attempts to improve the activity, bioavailability, and physicochemical properties of potential drug candidates, often with much success. In our case, these modifications seemed to have the greatest effect on both CCK and opioid activities of the hydrazide-linked bifunctional peptides as measured by in vitro binding and functional assays. A free amine moiety in the CCK region seemed to play a role in making a favorable conformation for the 
opioid, especially for $\mu$ receptor activity, whereas the protecting group did not seem to be essential for CCK activities. N-Terminal modification was done where chirality was reversed. There did not appear to be a great difference in CCK and opioid activities between ligands 5 and 6, which have a Boc group and an Ac group at the N-terminus, respectively. This result coincides with the previous observation that the acetyl protected tetrapeptide (Ac-Trp-Lys (Tac)-Asp-NMePhe- $\mathrm{NH}_{2}$ ) is equipotent to the Boc protected analogue for CCK receptors. 23 , 26 Both Boc- or Ac-protected tetrapeptides showed the same good potency and selectivity for the CCK-1 receptor, even with a big difference in physicochemical properties.

In our earlier studies 10,11 on structure-activity relationships, we showed that $N$-methylation of the Nle residue in the 2' position of the CCK pharmacophore was necessary for balanced and high CCK-1/CCK-2 binding affinities depending on 1' position modification. NMR studies ${ }^{27}$ showed that cis/trans isomerization of the NMeNle residue may be related to the selectivity. The $N$-methylation of $\mathrm{Nl}^{2}$ in 7 led to increases of binding affinities at both CCK receptors (5- and 7-fold at CCK-1 and CCK-2 receptors, respectively) and at opioid receptors (55-, and 2-fold at $\delta$ and $\mu$ opioid receptors, respectively), relative to 1 . Also, this modification gave the highest efficacy $\left(\mathrm{EC}_{50}=0.64 \mathrm{nM}\right)$ at the $\mu$ opioid receptor. However, despite its relatively high CCK and opioid binding affinities and very high efficacy at $\mu$ opioid receptor, ligand 7 lost CCK antagonist activity and $\mu$ opioid agonist activity while unexpectedly showing partial agonist activity at the CCK receptor. This result suggests that CCK and opioid pharmacophores have a common backbone requirement for both receptors and that substitution of $D$-Trp ${ }^{4}$-NMeNle $2^{\prime}$ is not tolerated at both receptors. Trp was introduced instead of $D$-Trp, leading to the ligand $\mathbf{5}$, which showed improved binding affinities at CCK receptors while retaining moderate opioid affinities. Also a large increase in its efficacy for the $\mu$ opioid receptor in GTP- $\gamma$-S binding and $\mu$ opioid agonist activity in the GPI assay were shown for this analogue with reversed $\mu$ selectivity over $\delta$. While the chirality of position $1^{\prime}$ does not affect CCK binding affinities and activities by itself, the constraint from $N$-methylation of 2' position restricts this moiety within a topographical space to give either a favorable or unfavorable conformation to CCK and opioid receptors. Considering the biological data, the backbone conformation achieved by the $\operatorname{Trp}^{1^{\prime}}-\mathrm{Nle}^{2^{\prime}}$ combination seems to favor both the CCK and opioid receptors.

The $o$-chlorophenylaminocarbonyl (Cpac) substituted lysine derivative, Lys(Cpac), ${ }^{23}$ was introduced into the $2^{\prime}$ position instead of Nle in compound $\mathbf{8}$ to give $\mathbf{9}$, which has more than 6fold increased CCK-1/CCK-2 binding affinities with high binding $(0.48 \mathrm{nM})$ and good efficacy in the GTP- $\gamma$-S binding $\left(\mathrm{EC}_{50}=1.3, E_{\max }=81 \%\right)$ for the $\delta$ opioid receptor. It is likely that this is because the NMePhe substitution in the 4 ' position of CCK pharmacophore plays a role in making a favorable structure for $\delta$ opioid receptor. Comparing $\mathbf{6}$, which has a $4^{\prime}$ Phe, with ligand $\mathbf{8}$, which has a NMePhe in the 4' position, again showed that 4' position modification affected not only CCK activities but also opioid activities. The CCK antagonist activity of $\mathbf{8}$ changed slightly in the functional assays, but the efficacy at opioid receptors was increased greatly with distinct $\delta$ selectivity $(\mu / \delta=10)$. In both GTP- $\gamma$-S and functional assays, $\delta$ opioid selectivity was greatly increased, which demonstrated the role of this position in determining $\delta$ opioid receptor activity. The backbone change by $N$-methyl modification of the $4^{\prime}$ position is more favorable for the $\delta$ opioid receptor conformation. It is interesting that the $1^{\prime}$ position of the CCK pharmacophore affects the $\mu$ opioid activity more than $\delta$ activity and vice versa for the $4^{\prime}$ position. In an earlier study, 28 we replaced this 4 ' position by the very bulky pyrenylalanine (Pya), which resulted in a loss of both CCK antagonist and $\mu$ and $\delta$ opioid agonist activities in functional assays, even though a slight decrease in both binding affinities was seen. From this observation, it appears that small differences in structure might cause great changes in the biological activity of the ligand.

In summary, most ligands retained their opioid activities, but often not their CCK activities, even though some of them showed good antagonist function for the CCK receptor. Comparing 
the two individual pharmacophores, one for the opioid receptors (Tyr- $D$-Ala-Gly-Phe- $\mathrm{NH}_{2}$ )

29 and the other for the CCK receptors (CCK-4), ${ }^{30}$ respectively, the hydrazide-linked

bifunctional peptides were found to have the same high activities for the opioid receptors, but relatively lower activities for CCK receptors. The conformation of the opioid portion of the hydrazide-linked bifunctional peptides was not changed on the basis of the biphalin halfstructure. The hydrazide linker appeared to play a role in maintaining the conformation for binding to the opioid receptors. On the contrary, the CCK portion of the bifunctional peptide possessed different conformations. In this case, CCK receptor binding was reduced because the rigidity of the hydrazide linker resulting in a decrease in CCK activity.

\section{Conclusions}

A series of hydrazide-linked bifunctional peptides have been synthesized and tested in an effort to optimize both opioid and CCK activities for the treatment of pain. These hydrazide-linked bifunctional peptides produced very potent $\delta$ and $\mu$ opioid agonist activities and moderately potent and very balanced CCK-1/CCK-2 antagonist activities. From structure-activity relationships, the hydrazide linker, which is inserted to combine opioid and CCK pharmacophores, is considered to play a role in making a desirable conformation for opioid receptors more so than for CCK receptors. Further, CCK pharmacophore modifications affect not only CCK potency but also opioid potency, which suggests that the two pharmacophores interact with each other to make one conformation or two different conformations for opioid and CCK receptors. From the biological profile of these peptide ligands, it was demonstrated that it is reasonable to build agonist function for opioid receptors and antagonist function for CCK receptors in a single structure. It is worth noting that two different pharmacophores for different G-protein coupled receptors (GPCRs) can be designed into one structure by rational design.

\section{Experimental Section}

All amino acid derivatives except 1-Adoc- $D$-Trp, 2-Adoc- $D$-Trp, Phe-OEt, and Boc-Lys (Cpac) were purchased from Novabiochem, Bachem, and Chem Impex International. 1-Adoc$D$-Trp, 2-Adoc- $D$-Trp, and Phe-OEt were prepared by well-established procedures. Boc-Lys (Cpac) was synthesized by the reaction of Boc-Lys with 2-chlorophenyl isocyanate in the presence of base. ${ }^{23}$ myo-[2- $\left.{ }^{3} \mathrm{H}-(\mathrm{N})\right]$-inositol, [tyrosyl-3,5- $\left.{ }^{3} \mathrm{H}(\mathrm{N})\right], D-\mathrm{Ala}^{2}-\mathrm{MePhe}^{4}$-glyol ${ }^{5}$ enkephalin (DAMGO), [tyrosyl-2,6- $\left.{ }^{3} \mathrm{H}(\mathrm{N})\right]-(2-D$-penicillamine,5- $D$-penicillamine) enkephalin (DPDPE), Bolton-Hunter radioiodinated chole-cystokinin octapeptide [CCK-8(s)], and $\left[{ }^{35}\right.$ S $]$ guanosine 5 - $(\gamma$-thio) triphosphate were purchased from Perkin-Elmer.

Cholecystokinin [CCK-8(s)] was purchased from American Peptide Company Inc. Bovine serum albumin (BSA), protease inhibitors, Tris, and other buffer reagents were obtained from SIGMA. Culture medium (MEM, DMEM, IMDM), penicillin/streptomycin, and fetal calf serum (FCS) were purchased from Gibco. Coupling reactions were monitored by TLC. TLC was performed on aluminum sheets coated with a $0.2 \mathrm{~mm}$ layer of silica gel $60 \mathrm{~F}_{254}$ Merck using the following solvent systems: (1) $\mathrm{CHCl}_{3}: \mathrm{MeOH}: \mathrm{AcOH}=90: 10: 3$, (2) EtOAc: $n$ $\mathrm{BuOH}$ : water: $\mathrm{AcOH}=5: 3: 1: 1$, and (3) $n$-BuOH:water: $\mathrm{AcOH}=4: 1: 1$; ninhydrin spray was used for detection. Analytical HPLC was performed on a Hewlett-Packard 1090 (C-18, Vydac, 4.6 $\times 250 \mathrm{~mm}, 5 \mu \mathrm{m})$ and preparative RP-HPLC on a Hewlett-Packard $1100(\mathrm{C}-18$, Vydac, $10 \times$ $250 \mathrm{~mm}, 10 \mu \mathrm{m}) .{ }^{1} \mathrm{H}$ NMR spectra were recorded on a Bruker DRX-500 spectrometer. Mass spectra were taken in the positive ion mode under ESI methods.

\section{TFA.H-Gly-Phe-OEt}

$\mathrm{HCl} \cdot \mathrm{H}-\mathrm{Phe}-\mathrm{OEt}$ (5.4 g, $23.4 \mathrm{mmol}$ ) was dissolved in $60 \mathrm{~mL}$ of DMF. Boc-Gly (4.56 g, 26 mmol, 1.1 equiv) and HOBt ( $3.52 \mathrm{~g}, 26 \mathrm{mmol}, 1.1$ equiv) were added to the mixture, which was cooled in an ice-bath for $10 \mathrm{~min}$. DCC (5.36 g, $26 \mathrm{mmol}, 1.1$ equiv) and NMM (2 equiv) 
were added, and the mixture was stirred for $30 \mathrm{~min}$ at $0{ }^{\circ} \mathrm{C}$ and for 1 day at room temperature. After checking the disappearance of the starting amine, DCU formed was filtered off. The filtrate was concentrated and diluted with $100 \mathrm{~mL}$ of EtOAc. The organic layer was washed with $2 \mathrm{~N} \mathrm{HCl}(20 \mathrm{~mL})$, saturated $\mathrm{NaHCO}_{3}(40 \mathrm{~mL})$, and finally brine $(40 \mathrm{~mL})$, followed by drying with anhydrous $\mathrm{Na}_{2} \mathrm{SO}_{4}$. The solution was evaporated under reduced pressure and dried in vacuo to give Boc-Gly-Phe-OEt as an oil. The oil was dissolved in cold TFA $(40 \mathrm{~mL})$ and stirred for $20 \mathrm{~min}$ at $0{ }^{\circ} \mathrm{C}$. The mixture was evaporated off and coevaporated with toluene (50 $\mathrm{mL}$, two times). The solid was filtered off, washed with toluene, and dried in vacuo to afford $8.2 \mathrm{~g}(96 \%)$ of TFA.H-Gly-Phe-OEt as a very hygroscopic powder: MS m/z 251.0 (M - TFA $+\mathrm{H})^{+}$.

\section{TFA-H-D-Ala-Gly-Phe-OEt}

TFA-H-Gly-Phe-OEt (7.30 g, $20 \mathrm{mmol})$ and Boc- $D$-Ala $(4.16 \mathrm{~g}, 22 \mathrm{mmol})$ were dissolved in DMF $(100 \mathrm{~mL})$ and cooled in ice-bath for $10 \mathrm{~min}$. BOP $(9.7 \mathrm{~g}, 22 \mathrm{~mol}), 2.97 \mathrm{~g}(22 \mathrm{mmol})$ of $\mathrm{HOBt}$, and $4.4 \mathrm{~mL}$ ( $40 \mathrm{mmol}$ ) of NMM were added to the reaction mixture, which stirred for $30 \mathrm{~min}$ at $0^{\circ} \mathrm{C}$ and for $7 \mathrm{~h}$ at room temperature. After checking for disappearance of the starting amine, the mixture was concentrated under reduced pressure, followed by dilution with EtOAc $(150 \mathrm{~mL})$ and $2 \mathrm{~N} \mathrm{HCl}(70 \mathrm{~mL})$. The organic layer was washed with saturated $\mathrm{NaHCO}_{3}(2 \times$ $15 \mathrm{~mL}$ ) and brine $(20 \mathrm{~mL})$ and dried over anhydrous $\mathrm{Na}_{2}-\mathrm{SO}_{4}$. After filtering, the solution was concentrated and dried in vacuo to give Boc- $D$-Ala-Gly-Phe-OEt as a sticky solid. The powder (about $19.7 \mathrm{mmol}$ ) was dissolved in cold TFA $(20 \mathrm{~mL})$ and stirred for $20 \mathrm{~min}$ at $0{ }^{\circ} \mathrm{C}$. The mixture was evaporated and coevaporated with toluene $(2 \times 50 \mathrm{~mL})$. The solid was washed with EtOAc $(2 \times 50 \mathrm{~mL})$ and dried to give $5.38 \mathrm{~g}(63 \%$, two-step yield $)$ of TFA.H-D-Ala-GlyPhe-OEt as a white powder: MS $m / z 321.9(\mathrm{M}-\mathrm{TFA}+\mathrm{H})^{+}$.

\section{Z-Tyr(BzI)-D-Ala-Gly-Phe-OEt}

Z-Tyr(Bzl)- $D$-Ala-Gly-Phe-OEt $(5.30 \mathrm{~g}, 81 \%$ yield) as a white power was prepared by the same coupling method as described above and isolated from EtOAc: analytical HPLC $t_{\mathrm{R}} 29.9$ min, purity $>95 \%$; MS m/z $708.9(\mathrm{M}+\mathrm{H})^{+}, 731.3(\mathrm{M}+\mathrm{Na})^{+}$.

\section{Z-Tyr(Bzl)-D-Ala-Gly-Phe-NH-NH}

Z-Tyr(Bzl)- $D$-Ala-Gly- Phe-OEt $(730 \mathrm{mg}$ ) in $10 \mathrm{~mL}$ of DMF was treated with $55 \%$ hydrazine $(1 \mathrm{~mL})$ for 1 day and triturated with water to give $660 \mathrm{mg}$ of pure Z-Tyr(Bzl)-D-Ala-Gly-Phe$\mathrm{NH}-\mathrm{NH}_{2}$ as a white powder in $95 \%$ yield: analytical HPLC $t_{\mathrm{R}} 24.0 \mathrm{~min}$, purity $>95 \%$; MS m/ $z 695.1(\mathrm{M}+\mathrm{H})^{+}$.

\section{Z-Tyr(Bzl)-D-Ala-Gly-Phe-NH-NH-Phe-Asp(OBzl)-Nle-Xxx-PG}

$\mathrm{Z}-\mathrm{Tyr}(\mathrm{Bzl})-D$-Ala-Gly-Phe-NH-NH $\mathrm{N}_{2}$ was coupled stepwise with 1.1 equiv of Boc-Phe, BocAsp(Bzl), and Boc-Nle using the standard BOP/HOBt procedure to afford pure Z-Tyr(Bzl)$D$-Ala-Gly-Phe-NH-NH-Phe-Asp(OBzl)-Nle-TFA [MS (M - TFA + H) ${ }^{+} 1160.2$; analytical HPLC $t_{\mathrm{R}} 28.7$ min, purity $>95 \%$ ] in 90\% yield. The heptapeptide was coupled with Boc- $D$ Trp, 1-Adoc- $D$-Trp, 2-Adoc- $D$-Trp, Boc-Trp, and Ac-Trp, respectively, and triturated with 5\% $\mathrm{NaHCO}_{3}$ to give crude Z-Tyr(Bzl)- $D$-Ala-Gly-Phe-NH-NH-Phe-Asp(OBzl)-Nle- $D$-Trp-Boc, Z-Tyr(Bzl)-D-Ala-Gly-Phe-NH-NH-Phe-Asp(OBzl)-Nle- $D$-Trp-1-Adoc, Z-Tyr(Bzl)- $D$-AlaGly-Phe-NH-NH-Phe-Asp(OBzl)-Nle- $D$-Trp-2-Adoc, Z-Tyr(Bzl)- $D$-Ala-Gly-Phe-NH-NHPhe-Asp(OBzl)-Nle-Trp-Boc, and Z-Tyr-(Bzl)-D-Ala-Gly-Phe-NH-NH-Phe-Asp(OBzl)Nle-Trp-Ac in quantitative yields in greater than $80 \%$ purity in all cases.

\section{TFA-H-Tyr-D-Ala-Gly-Phe-NH-NH-Phe-Asp-Nle-D-Trp-Boc (1)}

Z-Tyr(Bzl)- $D$-Ala-Gly-Phe-NH-NH-Phe-Asp(OBzl)-Nle- $D$-Trp-Boc was hydrogenated using $\mathrm{Pd}-\mathrm{C}$ as a catalyst for 2 days at room temperature, purified by preparative RP-HPLC 
(20-70\% of acetonitrile within $25 \mathrm{~min}$ ), and lyophilized to give pure $\mathbf{1}$ as a white powder in $67 \%$ yield.

TFA-H-Tyr-D-Ala-Gly-Phe-NH-NH-Phe-Asp-Nle-D-Trp-1-Adoc (2)

Z-Tyr(Bzl)-D-Ala-Gly-Phe-NH-NH-Phe-Asp(OBzl)-Nle- $D$-Trp-1-Adoc was hydrogenated using $\mathrm{Pd}-\mathrm{C}$ as a catalyst for 2 days at room temperature, purified by preparative RP-HPLC (20-50\% of acetonitrile within $30 \mathrm{~min}$ ), and lyophilized to give pure 2 as a white powder in $57 \%$ yield.

TFA-H-Tyr-D-Ala-Gly-Phe-NH-NH-Phe-Asp-Nle-D-Trp-2-Adoc (3)

Z-Tyr(Bzl)-D-Ala-Gly-Phe-NH-NH-Phe-Asp(OBzl)-Nle- $D$-Trp-2-Adoc was hydrogenated using $\mathrm{Pd}-\mathrm{C}$ as a catalyst for 2 days at room temperature, purified by preparative RP-HPLC (20-50\% of acetonitrile within $25 \mathrm{~min}$ ), and lyophilized to give pure 3 as a white powder in $62 \%$ yield.

\section{TFA-H-Tyr-D-Ala-Gly-Phe-NH-NH-Phe-Asp-Nle-D-Trp-H (4)}

To the solution of Z-Tyr(Bzl)- $D$-Ala-Gly-Phe-NH-NH-Phe-Asp-(OBzl)-Nle- $D$-Trp-Boc in DCM were added $1 \mathrm{~mL}$ of TFA and $0.1 \mathrm{~mL}$ of anisole. After stirring for $30 \mathrm{~min}$ at $0{ }^{\circ} \mathrm{C}$, the mixture was evaporated to an oil and triturated with ether to give Z-Tyr(Bzl)-D-Ala-Gly-PheNH-NH-Phe-Asp(OBzl)-Nle-D-Trp-H as a white powder. The Z-, Bzl-protected octapeptide was hydrogenated using $\mathrm{Pd}-\mathrm{C}$ as a catalyst for 2 days at room temperature, purified by preparative RP-HPLC (10-60\% of acetonitrile within $25 \mathrm{~min}$ ), and lyophilized to give pure 4 as a white powder in $45 \%$ yield.

\section{TFA-H-Tyr-D-Ala-Gly-Phe-NH-NH-Phe-Asp-Nle-Trp-Boc (5)}

Z-Tyr(Bzl)-D-Ala-Gly-Phe-NH-NH-Phe-Asp(OBzl)-Nle-Trp-Boc was hydrogenated using $\mathrm{Pd}-\mathrm{C}$ as a catalyst for 2 days at room temperature, purified by preparative RP-HPLC (20-60\% of acetonitrile within $25 \mathrm{~min}$ ), and lyophilized to give pure $\mathbf{5}$ as a white powder in $32 \%$ yield.

\section{TFA-H-Tyr-D-Ala-Gly-Phe-NH-NH-Phe-Asp-Nle-Trp-Ac (6)}

Z-Tyr(Bzl)-D-Ala-Gly-Phe-NH-NH-Phe-Asp(OBzl)-Nle-Trp-Ac was hydrogenated using $\mathrm{Pd}-\mathrm{C}$ as a catalyst for 2 days at room temperature, purified by preparative RP-HPLC (20-60\% of acetonitrile within $25 \mathrm{~min}$ ), and lyophilized to give pure $\mathbf{6}$ as a white powder in $35 \%$ yield.

\section{Z-Tyr-D-Ala-Gly-Phe-NH-NH-Phe-Asp-NMeNle-D-Trp-Boc (7)}

$\mathrm{Z}-\mathrm{Tyr}(\mathrm{Bzl})-D$-Ala-Gly-Phe-NH-NH $\mathrm{N}_{2}$ was coupled stepwise with 1.1 equiv of Boc-Phe, Boc$\mathrm{Asp}(\mathrm{Bzl})$, and Boc-NMeNle using the standard $\mathrm{BOP} / \mathrm{HOBt}$ procedure to afford pure Z-Tyr (Bzl)- $D$-Ala-Gly-Phe-NH-NH-Phe-Asp(OBzl)-NMeNle-TFA [MS m/z $1174.3(\mathrm{M}+\mathrm{H})^{+}$; analytical HPLC $t_{\mathrm{R}} 28.4 \mathrm{~min}$ ] in $90 \%$ yield. The heptapeptide was coupled with Boc- $D$-Trp and triturated with $5 \% \mathrm{NaHCO}_{3}$ to give crude Z-Tyr(Bzl)- $D$-Ala-Gly-Phe-NH-NH-Phe-Asp (OBzl)-NMeNle- $D$-Trp-Boc [MS $\mathrm{m} / z$ 1488.3 $(\mathrm{M}+\mathrm{Na})^{+}$; analytical HPLC $t_{\mathrm{R}} 36.6 \mathrm{~min}$ ] in quantitative yield. The octapeptide was hydrogenated using $\mathrm{Pd}-\mathrm{C}$ as a catalyst for 2 days at room temperature, purified by preparative RP-HPLC (20-60\% of ac-etonitrile within $25 \mathrm{~min}$ ), and lyophilized to give pure 7 as a white powder in $23 \%$ yield.

\section{TFA-H-Tyr-D-Ala-Gly-Phe-NH-NH-NMePhe-Asp-Yyy-Trp-Ac (8, 9)}

$\mathrm{H}-\mathrm{Tyr}-\mathrm{D}$-Ala-Gly-Phe-NH-NH $\mathrm{N}_{2}$ was coupled stepwise with 1.1 equiv of Boc-NMePhe, BocAsp(Bzl), Boc-Nle (or Boc-Lys(Cpac)), and finally Ac-Trp to give Z-Tyr(Bzl)-D-Ala-GlyPhe-NH-NH-NMePhe-Asp(OBzl)-Yyy-Trp-Ac as a white powder in 55\% yield. The coupling of Boc-Asp(Bzl) to Z-Tyr(Bzl)-D-Ala-Gly-Phe-NH-NH-NMePhe-TFA [MS $m / z$ 856.2 (M + 
$\mathrm{H})^{+}$; analytical HPLC $\left.t_{\mathrm{R}} 25.3 \mathrm{~min}\right]$ was not completed for 1 day. There was still starting peptide, which was removed by solid-phase extraction using Sep-Pak Catridges (Waters). After completion of chain elongation, the protected peptides were hydrogenated using $\mathrm{Pd}-\mathrm{C}$ as a catalyst for 2 days at room temperature, purified by preparative RP-HPLC (20-50\% of acetonitrile within $25 \mathrm{~min}$ for $\mathbf{8}, 10-50 \%$ of acetonitrile within $30 \mathrm{~min}$ for $\mathbf{9}$ ), and lyophilized to give pure 8 and $\mathbf{9}$ as a white powder in $56 \%$ and $20 \%$, respectively.

\section{Cell Lines}

The cDNA for the human DOR was a gift from Dr. Brigitte Kieffer (IGBMC, Illkirch, France). The cDNA for the rat MOR was a gift from Dr. Huda Akil (University of Michigan). The cDNA for the human CCK-1 and CCK-2 was a gift from Dr. Alan Kopin (Tufts University). Stable expression of the human CCK-1 (CMV Tag2) and CCK-2 (pCDNA HisXpress) receptors in HEK 293 cells was produced by transfecting the cells with the respective cDNA by calcium phosphate precipitation followed by clonal selection in neomycin. Stable expression of the rat MOR (pCDNA3) and the human DOR (pCDNA3) in the neuroblastoma cell line HN9.10 was achieved with the same method. Expression of the respective receptors was initially verified and the level of expression periodically monitored by radioligand saturation analysis (see below). All cells were maintained at a $37{ }^{\circ} \mathrm{C}, 95 \%$ air $/ 5 \% \mathrm{CO}_{2}$, humidified atmosphere in a Forma Scientific incubator in DMEM with $10 \%$ BSA and $100 \mathrm{U}$ $\mathrm{mL}$ penicillin $/ 100 \mu \mathrm{g} \mathrm{mL}$ streptomycin.

\section{Radioligand Labeled Binding Assays. Opioid Receptors}

Crude membranes were prepared as previously described ${ }^{31}$ from the transfected cells that express the MOR or the DOR. The protein concentration of the membrane preparations was determined by the Lowry method, and the membranes were stored at $-80{ }^{\circ} \mathrm{C}$ until use. Membranes were resuspended in assay buffer [ $50 \mathrm{mM}$ Tris, $\mathrm{pH} 7.4$, containing $50 \mu \mathrm{g} / \mathrm{mL}$ bacitracin, $30 \mu \mathrm{M}$ bestatin, $10 \mu \mathrm{M}$ captopril, $100 \mu \mathrm{M}$ phenylmethylsulfonylfluoride (PMSF), $1 \mathrm{mg} / \mathrm{mL}$ BSA]. For saturation analysis, six concentrations of $\left[{ }^{3} \mathrm{H}\right]$-DAMGO $(0.02-6 \mathrm{nM}$, $47.2 \mathrm{Ci} / \mathrm{mmol})$ or six concentrations of $\left[{ }^{3} \mathrm{H}\right] \mathrm{DPDPE}(0.1-10 \mathrm{nM}, 44 \mathrm{Ci} / \mathrm{mmol})$ were each mixed with $200 \mu \mathrm{g}$ of membranes from MOR or DOR expressing cells, respectively, in a final volume of $1 \mathrm{~mL}$. For competition analysis, 10 concentrations of a test compound were each incubated with $50 \mu \mathrm{g}$ of membranes from MOR- or DOR-expressing cells and the $K_{\mathrm{d}}$ concentration of $\left[{ }^{3} \mathrm{H}\right]$ DAMGO $(1.0 \mathrm{nM}, 50 \mathrm{Ci} / \mathrm{mmol})$ or of $\left[{ }^{3} \mathrm{H}\right]$-DPDPE $(1.0 \mathrm{nM}, 44 \mathrm{Ci} / \mathrm{mmol})$, respectively. Naloxone at $10 \mu \mathrm{M}$ was used to define the nonspecific binding of the radioligands in all assays. All samples were carried out in duplicate. The samples were incubated in a shaking water bath at $25{ }^{\circ} \mathrm{C}$ for $3 \mathrm{~h}$, followed by rapid filtration through Whatman grade GF/B filter paper (Gaithersburg, MD) presoaked in $1 \%$ polyethyleneimine and washing four times each with 2 $\mathrm{mL}$ of cold saline, and the radioactivity was determined by liquid scintillation counting (Beckman LS5000 TD).

\section{CCK Receptors}

All assays were performed using whole cells preparations expressing either the human CCK-1 or CCK-2 receptors. The assay buffer used was low-glucose DMEM, pH 7.4, in the presence of $0.5 \mathrm{mg} / \mathrm{mL}$ BSA and protease inhibitors, as above. For saturation analysis, 12 concentrations (12.5 pM-4 nM) of unlabeled CCK-8(s)/[ $\left.{ }^{125} \mathrm{I}\right] \mathrm{CCK}-8$ (labeled-to-unlabeled ratios 1:25 to 1:65) were incubated with 200000 cells/assay tube in a final volume of $1 \mathrm{~mL}$. For $\left[{ }^{125} \mathrm{I}\right] \mathrm{CCK}-8$ (2200 $\mathrm{Ci} / \mathrm{mmol}$ )/ligand competition analysis, 10 different concentrations (from $10^{-13}$ to $10^{-4} \mathrm{M}$ ) of each test peptide were mixed with [ $\left.{ }^{125} \mathrm{I}\right] \mathrm{CCK}-8(1.0-1.5 \mathrm{pM})$ and 200000 cells/assay tube in a final volume of $1 \mathrm{~mL}$ in assay buffer. Nonspecific binding was defined as that of $\left[{ }^{125} \mathrm{I}\right] \mathrm{CCK}-8$ bound in the presence of $1 \mu \mathrm{M}$ unlabeled CCK-8. All samples were done in duplicate. Incubations were carried out at $30^{\circ} \mathrm{C}$ for $60 \mathrm{~min}$ in a shaking water bath, and the reaction was 
terminated by rapid filtration through Whatman GF/ B filter paper (presoaked in polyethyleneimine) and washed four times with $2 \mathrm{~mL}$ of ice-cold saline. The radioactivity was determined by $\gamma$-counting (Packard Cobra II $\gamma$-Counter). The $\log \mathrm{IC}_{50} \pm \mathrm{SEM}$ of a peptide for each receptor type was determined by nonlinear regression analysis of data pooled from at least two independent experiments using GraphPad Prism4 (Graph Pad, San Diego, CA). The $K_{\mathrm{i}}$ values were calculated as the antilogarithmic value of the $\mathrm{IC}_{50}$. For competition analysis using $\left[{ }^{3} \mathrm{H}\right]$ DAMGO or $\left[{ }^{3} \mathrm{H}\right] \mathrm{DPDPE}$, the $K_{\mathrm{i}}$ values were calculated from the $\mathrm{IC}_{50}$ by the Cheng and Prusoff equation.

\section{[ ${ }^{35}$ S]GTP-y-S Binding Assay}

The method was carried out according to that previously described. ${ }^{32}$ Membrane preparation $(10 \mu \mathrm{g})$ to a final volume of $1 \mathrm{~mL}$ incubation mix (50 mM Hepes, pH 7.4, 1 mM EDTA, $5 \mathrm{mM}$ $\mathrm{MgCl}_{2}, 30 \mu \mathrm{M}$ GDP, $1 \mathrm{mM}$ dithiothreitol, $100 \mathrm{mM} \mathrm{NaCl}, 0.1 \mathrm{mM}$ PMSF, $0.1 \%$ BSA, $0.1 \mathrm{nM}$ $\left[{ }^{35} \mathrm{~S}\right] \mathrm{GTP}-\gamma$-S) was added along with various concentrations, in duplicate or triplicate, of the test drug and incubated for $90 \mathrm{~min}$ at $30^{\circ} \mathrm{C}$ in a shaking water bath. Reactions were terminated by rapid filtration through Whatman $\mathrm{GF} / \mathrm{B}$ filters (presoaked in water), followed by four washes with $4 \mathrm{~mL}$ of ice-cold wash buffer ( $50 \mathrm{mM}$ Tris, $5 \mathrm{mM} \mathrm{MgCl}_{2}, 100 \mathrm{mM} \mathrm{NaCl}, \mathrm{pH}$ 7.4). The radioactivity was determined by liquid scintillation counting as above. The basal level of $\left.{ }^{35} \mathrm{~S}\right] \mathrm{GTP} \gamma \mathrm{S}$ binding was defined as the amount bound in the absence of any test drug. Nonspecific binding was determined in the presence of $10 \mu \mathrm{M}$ unlabeled GTP- $\gamma$-S. Total binding was defined as the amount of radioactivity bound in the presence of test drug. The effect of the drug at each concentration on $\left[{ }^{35} \mathrm{~S}\right]-\mathrm{GTP}-\gamma-\mathrm{S}$ binding was calculated as a percentage by the following equation: [total bound - basal]/[basal - nonspecific] $\times 100$. Data were expressed as $\log \mathrm{EC}_{50} \pm$ standard error from at least two independent experiments analyzed by nonlinear regression analysis using GraphPad Prism4. The $E_{\max }$ values were expressed as mean \pm standard error.

\section{GPI and MVD in Vitro Bioassays}

The in vitro tissue bioassays were performed as described previously. ${ }^{33-35} \mathrm{IC}_{50}$ values represent the mean of no less than four tissues. $\mathrm{IC}_{50}$ estimates, relative potency estimates, and their associated standard errors were determined by fitting the data to the Hill equation by a computerized nonlinear least-squares method. In the MVD assay, male ICR mice under ether anesthesia were sacrificed by cervical dislocation, and the vasa deferentia was removed. The tissue were tied to a gold chain with suture silk and mounted between platinum wire electrodes in 20-mL organ baths at a tension of $0.5 \mathrm{~g}$ and bathed in oxygenated $\left(95 \% \mathrm{O}_{2}, 5 \% \mathrm{CO}_{2}\right)$ magnesium-free Kreb's buffer at $37^{\circ} \mathrm{C}$. They were stimulated electrically $(0.1 \mathrm{~Hz}$, single pulses, $2.0 \mathrm{~ms}$ duration) at supramaximal voltage. Following an equilibrium period, compounds were added to the bath cumulatively in volumes of $14-16 \mathrm{~mL}$ until maximum inhibition is reached. Response to an $\mathrm{IC}_{50}$ dose of DPDPE $(10 \mathrm{nM})$ was measured to determine tissue integrity before compound testing begins.

In the GPI bioassay, male Hartley guinea pigs under anesthesia were sacrificed by decapitation and a nonterminal portion of the ileum was removed. The LMMP were carefully separated from the circular muscle and were cut into strips. The tissues were tied to a gold chain with suture silk, mounted between platinum wire electrodes in 20-mL baths at a tension of $1 \mathrm{~g}$ containing $37{ }^{\circ} \mathrm{C}$ oxygenated $\left(95 \% \mathrm{O}_{2}, 5 \% \mathrm{CO}_{2}\right) \mathrm{Kreb}$ 's buffer $(118 \mathrm{mM} \mathrm{NaCl}, 4.7 \mathrm{mM} \mathrm{KCl}$, $2.5 \mathrm{mM} \mathrm{CaCl}_{2}, 1.19 \mathrm{mM} \mathrm{KH}_{2} \mathrm{PO}_{4}, 1.18 \mathrm{mM} \mathrm{MgSO}_{4}, 25 \mathrm{mM} \mathrm{NaHCO}_{3}$, and $11.48 \mathrm{mM}$ glucose), and allowed to equilibrate for $15 \mathrm{~min}$. The tissues were stimulated electrically ( 0.1 $\mathrm{Hz}, 0.4 \mathrm{~ms}$ duration) at supramaximal voltage. Following an equilibration, the compound was added to the baths in 15-60 $\mu \mathrm{L}$ aliquots until maximum inhibition was observed. Percent inhibition was calculated by using the average contraction height for 1 min preceding the addition of the compound divided by the contraction height 3 min after exposure to the dose 
of the compound. Response to an $\mathrm{IC}_{50}$ dose of PL-017 (10 nM) was measured to determine tissue integrity before compound testing begins.

\section{Functional Assays for CCK}

Male Hartley guinea pigs under ether anesthesia were killed by decapitation, and a nonterminal portion of the ileum was removed. The longitudinal muscle with myenteric piexus (LMMP) was carefully separated from the circular muscle and cut into strips as described previously. 36 These tissues were tied to gold chains with suture silk and mounted between platinum wire electrodes in 20-mL organ baths at a tension of $1 \mathrm{~g}$ and bathed in oxygenated $\left(95 \% \mathrm{O}_{2}, 5 \%\right.$ $\left.\mathrm{CO}_{2}\right)$ Kreb's bicarbonate buffer at $37^{\circ} \mathrm{C}$. Tissues were stimulated electrically $(0.1 \mathrm{~Hz}, 0.4 \mathrm{~ms}$ duration) at supramaximal voltage to stabilize baseline force and tissue health. Response to an $\mathrm{IC}_{50}$ dose of PL-017 $(100 \mathrm{nM})$ was measured to determine tissue integrity before analogue testing began. Following an equilibration period, tissues were challenged with $\mathrm{KCl}(67 \mathrm{mM})$ to determine initial maximal muscle contractility.

An initial noncumulative CCK-8 dose-response curve was constructed using concentrations from 1 to $100 \mathrm{mM}$. The test compound was added to the bath in concentrations from 1 to 1000 $\mathrm{mM}$. If no agonist activity was observed, 3 min later a dose of CCK- 8 was added to determine the test compound's antagonist activity until a complete CCK- 8 dose-response curve had again been reconstructed using a dose of antagonist that seemed to cause a 3-fold shift rightward. Tissues were again challenged with $\mathrm{KCl}$ to determine tissue changes during the assay. After thorough washing, electrical stimulation was again applied, tissue resiliency tested with 100 nM PL-017, and an opioid dose-response curve was constructed with the test compound.

For CCK studies, contraction height was calculated as a percentage of the maximal $\mathrm{KCl}$ contraction and calculated as an $A_{50}$. For opioid studies, percentage inhibition was calculated using the average tissue contraction height for 1 min preceding the addition of the agonist divided by the contraction height $3 \mathrm{~min}$ after exposure to the dose of agonist. $\mathrm{IC}_{50}$ values represent the mean to not less than three tissues. $A_{50}, \mathrm{IC}_{50}$, and $E_{\max }$ estimates were determined by computerized nonlinear least-squares analysis.

\section{Supplementary Material}

Refer to Web version on PubMed Central for supplementary material.

\section{Acknowledgements}

The work was supported by a grant from the USDHS, National Institute on Drug Abuse, DA-12394. We thank Ms. Adrienne Begaye for technical assistance and Ms. Margie Colie for assistance with the manuscript.

\section{References}

1. Wiesenfeld-Hallin Z, Lucas GA, Alster P, Xu XJ, Hokfelt T. Cholecystokinin/opioid interaction. Brain Res 1999;848:78-89. [PubMed: 10612699]

2. Itoh S, Katsuura G, Maeda Y. Caerulein and cholecystokinin suppress $\beta$-endomorphin-induced analgesia in the rat. Eur J Pharmacol 1982;80:421-425. [PubMed: 6286327]

3. Dickenson AH. Mechanisms of the analgesic actions of opiates and opioids. Br Med Bull 1991;47:690702. [PubMed: 1665377]

4. Faris PL, Komisaruk BP, Watkins LR, Mayer DJ. Evidence for the neuropeptide cholecystokinin as an antagonist of opiate analgesia. Science 1983;219:310-312. [PubMed: 6294831]

5. Heinricher MM, Neubert MJ. Neural basis for the hyperalgesic action of cholecystokinin in the rostral ventromedial medulla. J Neurophysiol 2004;92:1982-1989. [PubMed: 15152023]

6. Lu L, Huang M, Liu A, Ma L. Cholecystokinin-B receptor antagonists attenuate morphine dependence and withdrawal in rats. Neuroreport 2000;11:829-832. [PubMed: 10757528] 
7. Suberg SN, Culhane ES, Carstens E, Watkins LR. The potentiation of morphine-induced inhibition of spinal transmission by proglumide, a putative cholecystokinin antagonist. Ann N Y Acad Sci 1985;448:660-662.

8. Watkins LR, Kinscheck IB, Mayer DJ. Potentiation of opiate analgesia and apparent reversal of morphine tolerance by proglumide. Science 1984;224:395-396. [PubMed: 6546809]

9. Magnuson DSK, Sullivan AF, Simmonet G, Roques BP, Dickenson AH. Differential interactions of cholecystokinin and FLFQPQRF- $\mathrm{NH}_{2}$ with $\mu$ and $\delta$ opioid antinociception in the rat spinal cord. Neuropeptides 1990;16:213-218. [PubMed: 2177165]

10. Hydrazide linked bifunctional peptides for the treatment of pain. In: Chorev, M.; Sawyer, TK., editors. Peptide Revolution: Genomics, Proteomics \& Therapeutics. Kluwer Academic Publishers; Dordrecht: 2004. p. 615-616.

11. Hruby VJ, Agnes RS, Davis P, Ma SW, Lee YS, Vanderah TW, Lai J, Porreca F. Design of novel peptide ligands which have opioid agonist activity and CCK antagonist activity for the treatment of pain. Life Sci 2003;73:699-704. [PubMed: 12801591]

12. Analogues of cholecystokinin26-33 selective for B-type CCK receptors possess opioid receptor agonist activity in vitro and in vivo: Evidence for similarities in CCK-B and opioid receptor requirements. In: Hodges, RS.; Smith, JA., editors. Peptides, Chemistry, Structure and Biology. Escom; Leiden: 1993. p. 669-671.

13. Nikiforovich GV, Hruby VJ. Examination of the conformational meaning of " $\delta$-address" in the dermenkephalin sequence. Biochem Biophys Res Commun 1990;173:521-527. [PubMed: 1979733]

14. Slaninova J, Knapp RJ, Wu J, Fang SN, Kramer T, Hruby VJ, Yamamura HI. Opioid receptor binding properties of analgesic analogues of cholecystokinin octapeptide. Eur J Pharmacol 1991;200:195198. [PubMed: 1663041]

15. Horan PJ, Mattia A, Bilsky EJ, Weber S, Davis TP, Yamamura HJ, Malatynska E, Appleyard SM, Slaninova J, Misicka A, Lipkowski AW, Hruby VJ, Porreca F. Antinociceptive Profile of biphalin, a dimeric enkephalin Analog. J Pharmacol Exp Ther 1993;265:1446-1454. [PubMed: 8389867]

16. Martinez J, Rodriguez M, Lignon MF, Galas MC, Amblard M, Rolland M, Mendre C, Fulcrand P, Laur J, Bernad N. Structure activity relationship of cholecystokinin: Analogs exhibiting selective activity. J Pharm Belg 1991;46:9-16. [PubMed: 2051303]

17. Singh L, Oles RJ, Field MJ, Atwal P, Woodruff GN, Hunter JC. Effect of CCK receptor antagonists on the antinociceptive reinforcing and gut motility properties of morphine. Br J Pharmacol 1996;118:1317-1325. [PubMed: 8818359]

18. Ghilardi JR, Allen CJ, Vigna SR, Mcvey DC, Mantyh P. Trigeminal dorsal root ganglion neurons express CCK receptor binding sites in the rat, rabbit, and monkey: Possible site of opiate-CCK analgesic interactions. J Neurosci 1992;12:4854-4866. [PubMed: 1334505]

19. Hill DR, Shaw TM, Woodruff GN. Binding sites for ${ }^{125}$ I-cholecystokinin in primate spinal cord are of the CCK-A subclass. Neurosci Lett 1998;89:133-139. [PubMed: 3134624]

20. Quock RM, Burkey TH, Varga E, Hosohata Y, Hosohata K, Cowell SM, Slate CA, Ehlert FJ, Roeske WR, Yamamura HI. The $\delta$ opioid receptor: Molecular pharmacology, signal transduction and the determination of drug efficacy. Pharmacol Rev 1999;51:503-532. [PubMed: 10471416]

21. Dal Forno G, Pietra C, Urciuoli M, van Amsterdam fT, Toson G. Evidence for two cholecystokinin receptors mediating the contraction of the guinea pig isolated ileum longitudinal muscle nuenteric plexus. J Pharmacol Exp Ther 1992;261:1056-1063. [PubMed: 1602372]

22. Dunlop J. CCK receptor antagonists. Gen Pharm 1998;31:519-524.

23. Sugg EE, Kimery MJ, Ding JM, Kenakin DC, Miller LJ, Queen KL, Rimele TJ. CCK-A receptor selective antagonists derived from the CCK-A receptor selective tetrapeptide agonist Boc-Trp-Lys (Tac)-Asp-MePhe-NH $\mathrm{NH}_{2}$ (A-71623). J Med Chem 1995;38:207-211. [PubMed: 7837233]

24. Pan GZ, Martinez J, Bodansky M, Jensen RT, Gardner JD. The importance of the amino acid in position 32 of cholecystokinin in determining its interaction with cholecystokinin receptors on pancreatic acini. Biochim Biophys Acta 1981;678:352-357. [PubMed: 6172156]

25. Low CMR, Black JW, Broughton HB, Buck IM, Davies JMR, Dunstone DJ, Hull RAD, Kalindjian SB, McDonald IM, Pether MJ, Shankley NP, Steel KIM. Development of peptide 3D structure mimetics: Rational design of novel peptoid cholecystokinin receptor antagonist. J Med Chem 2000;43:3505-3517. [PubMed: 11000005] 
26. Elliott RL, Kopecka H, Bennett MJ, Shue YK, Craig R, Lin CW, Bianchi BR, Miller TR, Witte DG, Stashko MA, Asin KE, Nikkel A, Bednarz L, Nadzan AM. Tetrapeptide CCK agonist: Structureactivity studies on modifications at the N-terminus. J Med Chem 1994;37:309-313. [PubMed: 8295219]

27. Hruby VJ, Fang S, Knapp R, Kazmierski W, Lui GK. Cholecystokinin analogues with high affinity and selectivity for brain membrane receptors. Int J Pept Protein Res 1990;35:566-573. [PubMed: 2401597]

28. Alves I, Cowell S, Lee YS, Tang C, Davis P, Porreca P, Hruby VJ. A Novel 3-step enantioselective synthesis of pyrenylalanine with subsequent incorporation into opioid, CCK, and mel-anotropin ligands. Biochem Biophys Res Commun 2004;318:335-340. [PubMed: 15120606]

29. Shimohigashi Y, Costa T, Chen HC, Rodbard D. Dimeric tetrapeptide enkephalins display extraordinary selectivity for the $\delta$ opiate receptor. Nature 1982;297:333-335. [PubMed: 6281658]

30. Horwell DC, Beeby A, Clark CR, Hughes J. Synthesis and binding affinities of cholecystokinin (3033) as probes for central nervous system cholecystokinin receptors. J Med Chem 1987;30:729-732. [PubMed: 3560164]

31. Lai J, Ma SW, Zhu RH, Rothman RB, Lentes KU, Porreca F. Pharmacological characterization of the cloned kappa opioid receptor as a kappa 1b subtype. NeuroReport 1994;5:2161-2164. [PubMed: 7865767]

32. Lorenzen A, Fuss M, Vogt H, Schwabe U. Measurement of guanine nucleotide-binding protein activation by $\mathrm{A} 1$ adenosine receptor agonists in bovine brain membranes: Stimulation of guanosine-5'-O-(3-[ $\left.{ }^{35} \mathrm{~S}\right]$ thio)triphosphate binding. Mol Pharmacol 1993;44:115-123. [PubMed: 8341267]

33. Polt R, Porreca F, Szabo L, Bilsky EJ, Davis P, Davis T, Horvath R, Abbruscato TJ, Yamamura HJ, Hruby VJ. Glycopeptide enkephalin analogues produce analgesia in mice: Evidence for penetration of the blood-brain barrier. Proc Natl Acad Sci USA 1994;91:7114-7118. [PubMed: 8041755]

34. Misicka A, Lipkowski AW, Horvath R, Davis P, Kramer TH, Yamamura HI, Hruby VJ.

Topographical requirements for delta opioid ligands: Common structural features of dermenkephalin and deltorphin. Life Sci 1992;51:1025-1032. [PubMed: 1326067]

35. Kramer TH, Shook JE, Kazmierski WK, Ayres EA, Wire WS, Hruby VJ, Burks TF. Novel peptidic $m u$ opioid antagonists: Pharmacologic characterization in vitro and in vivo. J Pharmacol Exp Ther 1989;249:544-551. [PubMed: 2566679]

36. Porreca F, Burks TF. The spinal cord as a site of opioid effects on gastrointestinal transit in the mouse. J Pharmacol Exsp Ther 1983;227:22-27. 


$$
\begin{aligned}
& \text { H-Tyr-D-Ala-Gly-Phe-NH-NH-Xxx-Asp-Yyy'-Zzz-PG } \\
& \text { opioid pharmacophore }
\end{aligned}
$$

Figure 1.

Design of hydrazide-linked bifunctional peptides. 


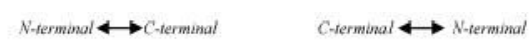

Figure 2.

Structure of hydrazide-linked bifunctional peptides synthesized in this study. 


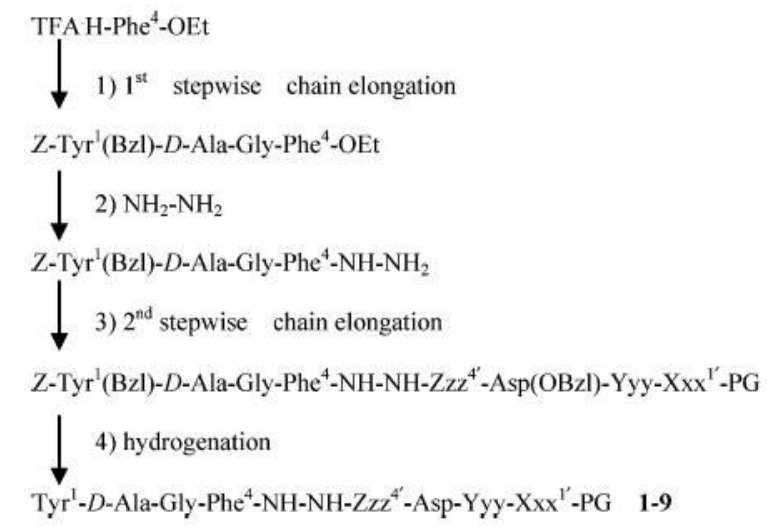

Figure 3.

Synthesis of hydrazide-linked bifunctional peptides. 


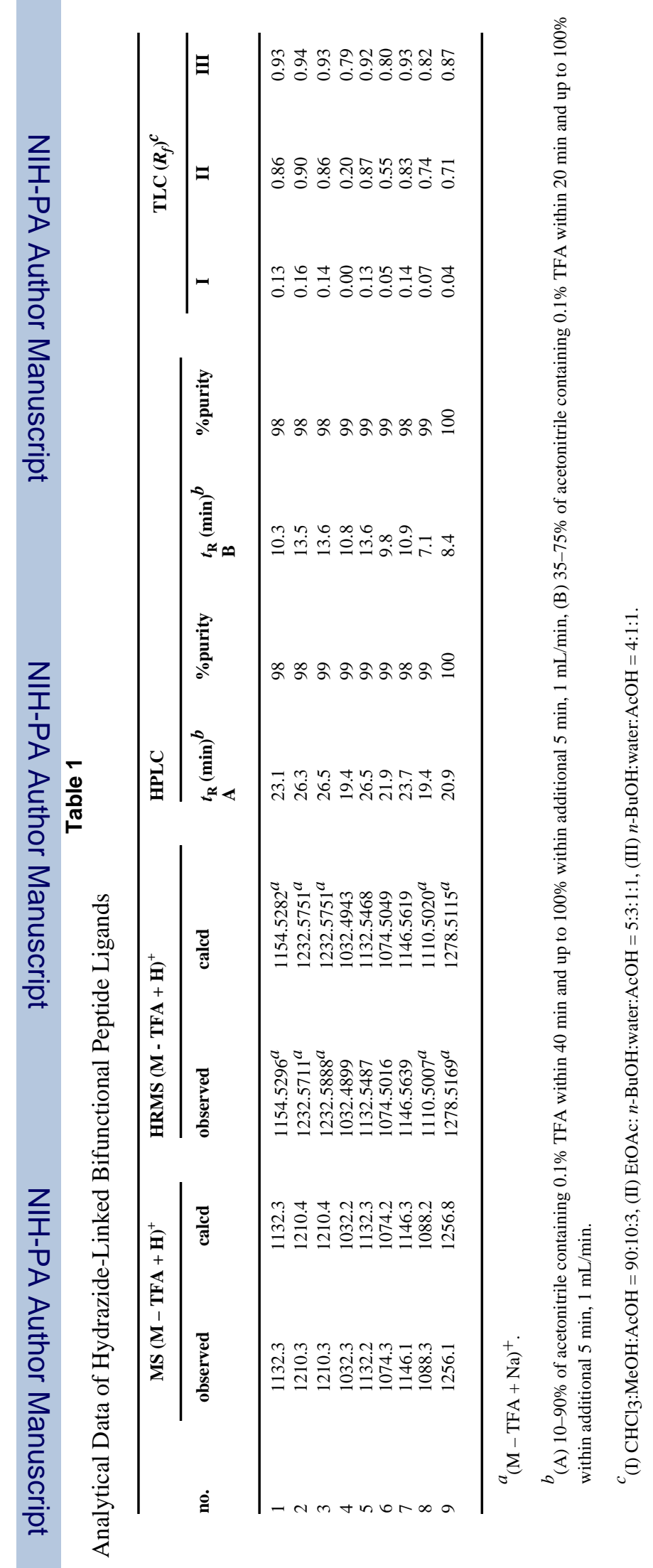

J Med Chem. Author manuscript; available in PMC 2006 October 17. 


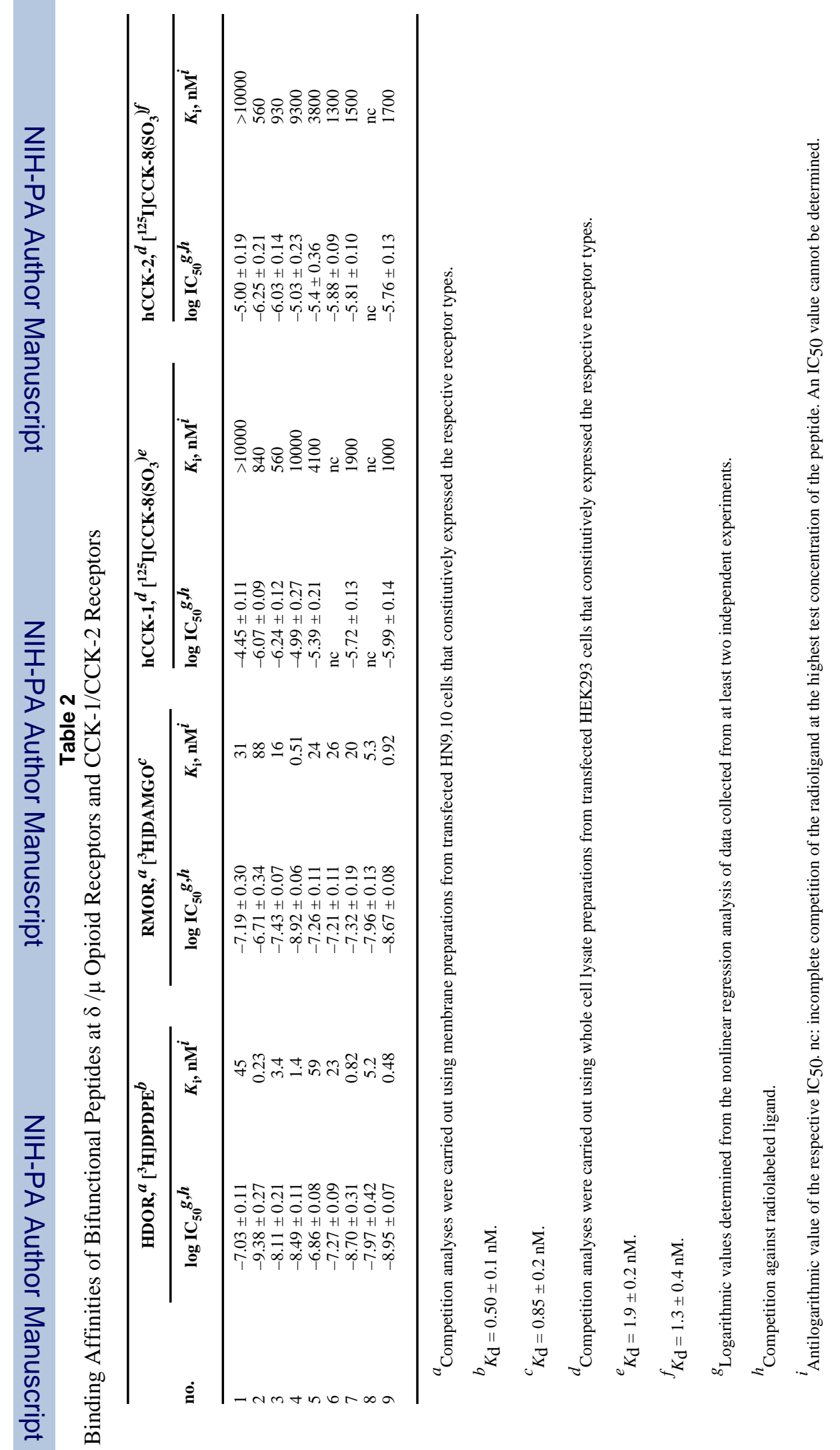


Table 3

Opioid Agonist Functional Activities in $\left[{ }^{35} \mathrm{~S}\right] \mathrm{GTP}-\gamma-\mathrm{S}$ Binding Assays

\begin{tabular}{|c|c|c|c|c|c|c|}
\hline \multirow[b]{2}{*}{ no. } & \multicolumn{3}{|c|}{$\operatorname{hDOR}^{a}$} & \multicolumn{3}{|c|}{$\operatorname{rMOR}^{a}$} \\
\hline & $\log \mathrm{EC}_{50} b$ & $\begin{array}{c}\mathrm{EC}_{50} \\
(\mathrm{nM})^{c}\end{array}$ & $E_{\max }(\%)^{d}$ & $\log \mathrm{EC}_{50} b$ & $\begin{array}{c}\mathbf{E C}_{50} \\
(\mathrm{nM})^{c}\end{array}$ & $E_{\max }(\%)^{d}$ \\
\hline $\begin{array}{l}1 \\
2 \\
3 \\
4 \\
5 \\
6 \\
7 \\
8 \\
9 \\
\text { biphalin } \\
\text { DPDPE } \\
\text { DAMGO }\end{array}$ & $\begin{array}{l}-7.13 \pm 0.27 \\
-7.56 \pm 0.42 \\
-8.25 \pm 0.24 \\
-8.03 \pm 0.16 \\
-7.57 \pm 0.17 \\
-7.26 \pm 0.15 \\
-7.60 \pm 0.30 \\
-9.28 \pm 0.68 \\
-8.88 \pm 0.05 \\
-8.95 \pm 0.17 \\
-8.80 \pm 0.25 \\
-\end{array}$ & $\begin{array}{c}74 \\
27 \\
5.6 \\
9.4 \\
27 \\
54 \\
26 \\
0.53 \\
1.3 \\
1.1 \\
1.6 \\
-\end{array}$ & $\begin{array}{l}100 \pm 8 \\
25 \pm 3 \\
61 \pm 4 \\
65 \pm 3 \\
54 \pm 3 \\
72 \pm 4 \\
120 \pm 12 \\
70 \pm 10 \\
81 \pm 1 \\
83 \pm 4 \\
69 \pm 4 \\
-\end{array}$ & $\begin{array}{l}-6.69 \pm 0.11 \\
-7.98 \pm 0.34 \\
-6.62 \pm 0.26 \\
-8.01 \pm 0.11 \\
-8.02 \pm 0.16 \\
-7.12 \pm 0.15 \\
-9.19 \pm 0.37 \\
-8.29 \pm 0.40 \\
-7.84 \pm 0.31 \\
- \\
-7.44 \pm 0.19\end{array}$ & $\begin{array}{c}210 \\
10 \\
240 \\
9.6 \\
9.5 \\
76 \\
0.64 \\
5.2 \\
15 \\
- \\
- \\
37\end{array}$ & $\begin{array}{l}170 \pm 4 \\
103 \pm 9 \\
60 \pm 5 \\
82 \pm 3 \\
83 \pm 4 \\
90 \pm 4 \\
130 \pm 13 \\
84 \pm 10 \\
33 \pm 3 \\
- \\
- \\
150 \pm 9\end{array}$ \\
\hline
\end{tabular}

$a_{\text {Expressed from } \mathrm{CHO} \text { cell. }}$

${ }^{b}$ Logarithmic values determined from the nonlinear regression analysis of data collected from at least two dependent experiments.

${ }^{c}$ Antilogarithmic value of the respective EC50.

${ }^{d}$ Net total bound/basal binding $\times 100 \pm$ SEM. 
Table 4

Functional Assay Result for Bifunctional Peptide Ligands at Opioid and CCK Receptors

\begin{tabular}{|c|c|c|c|c|}
\hline \multirow[b]{2}{*}{ no. } & \multicolumn{2}{|c|}{ opioid, $\mathrm{IC}_{50}(\mathrm{nM})^{a}$} & \multicolumn{2}{|c|}{ CCK GPI/LMMP } \\
\hline & $\operatorname{MVD}(\delta)$ & GPI $(\mu)$ & $\operatorname{agonist}\left(A_{50}\right) b$ & antagonist, $\operatorname{Ke}(\mathrm{nM}) c$ \\
\hline 1 & $24 \pm 5$ & $460 \pm 130$ & $0 \%$ at $1 \mu \mathrm{M}$ & $6.5 \pm 0.8$ \\
\hline 2 & $38 \pm 6$ & $640 \pm 200$ & $0 \%$ at $1 \mu \mathrm{M}$ & $44 \pm 12$ \\
\hline 3 & $84 \pm 11$ & $1200 \pm 270$ & $0 \%$ at $1 \mu \mathrm{M}$ & $150 \pm 15$ \\
\hline 4 & $26 \pm 5$ & $81 \pm 21$ & $0 \%$ at $1 \mu \mathrm{M}$ & $59 \pm 13$ \\
\hline 5 & $230 \pm 31$ & $55 \pm 6$ & $0 \%$ at $1 \mu \mathrm{M}$ & $14 \pm 3$ \\
\hline 6 & $36 \pm 18$ & $28 \pm 5$ & $0 \%$ at $1 \mu \mathrm{M}$ & $33 \pm 8$ \\
\hline 7 & $42 \pm 15$ & $0 \%$ at $1 \mu \mathrm{M}$ & $5 \%$ at $1 \mu \mathrm{M}$ & none at $1 \mu \mathrm{M}$ \\
\hline 8 & $5.1 \pm 0.3$ & $62 \pm 13$ & $0 \%$ at $1 \mu \mathrm{M}$ & $38 \pm 7$ \\
\hline 9 & $26 \pm 3$ & $200 \pm 30$ & $0 \%$ at $1 \mu \mathrm{M}$ & $150 \pm 34$ \\
\hline biphalin & $2.7 \pm 1.5$ & $8.8 \pm 0.3$ & - & - \\
\hline SNF9007 & $29 \pm 10$ & $220 \pm 81$ & $0 \%$ at $300 \mathrm{nM}$ & $66 \pm 14$ \\
\hline
\end{tabular}

${ }^{a}$ Concentration at $50 \%$ inhibition of muscle concentration at electrically stimulated isolated tissues.

${ }^{b}$ Contraction of isolated tissue relative to initial muscle contraction with $\mathrm{KCl}$.

${ }^{c}$ Inhibitory activity against the CCK-8 induced muscle contraction. Ke: concentration of antagonist needed to inhibit CCK-8 to half its activity. 